\title{
Globalization and the Cultural Effects of the World- Economy in a Semiperiphery: The Emergence of African Indigenous Churches in South Africa
}

by

\author{
Dr. Dawid Venter \\ Dept. of Anthropology and Sociology \\ University of the Western Cape \\ Bellville, South Africa \\ email: div@maties.sun.ac.za
}

\begin{abstract}
Cite: Dawid Venter. (1999). "Globalization and the Cultural Effects of the WorldEconomy in a Semiperiphery: The Emergence of African Indigenous Churches in South Africa." Journal of World-Systems Research http://jwsr.ucr.edu/ 5: 104-126.

(C) 1999 Dr. Dawid Venter.
\end{abstract}

[Page 104]

Journal of World-Systems Research

\begin{abstract}
Applied to religious phenomena, globalization theories which explain the emergence of an interdependent world-system provide the largest possible macroframework against which to view both societal and individual interactions. While both individual decisions and national forces are important and legitimate concerns, consideration of how these relate to globalization present an important additional analytical level which should not be ignored. Such macro-structural explanations are usually neglected in accounts of the rise of African Indigenous Churches (AICs), due to an affinity among AIC specialists for a focus on micro-variables. Where macro-variables are incorporated in analyses (e.g. Barrett 1968, Daneel 1987), these tend to focus on the effects of colonialism within the national sphere.
\end{abstract}

The application of globalization theories to religious movements is relatively undeveloped, and so what follows is by necessity exploratory. Roland Robertson, the pioneer in this field, has analysed how state-religion tensions across the globe arise from the politicization of religion, and the religionization of politics - the result of globalization (Robertson 1985, 1987, 1989, 1992). Other attempts at harnessing globalization theory to religious phenomena include an analysis of Anglo-American religion (P Smith 1986), Catholicity (Robertson 1987a), Japanese religion (Robertson 1987b), and Islam (Akbar \& Donnan 1994). Several anthologies have examined the relationship of religion to globality, particularly in relation to the political order (e.g. Swatos 1989; Robertson \& Garrett 1991; cf. McNeill 1994). More recently Peter Beyer (1994) offered a theoretical and applied examination of the topic, while Raymond Bulman (1996) examined the implications of theology for world-systems analysis. 
My overall purpose in this article is to demonstrate theoretically -- by using J De Wet's (1994) description of the emergence of Zionist-Apostolic churches in the Eastern former homeland of Transkei -- how globalization trends articulated with national socioeconomic developments in South Africa to contribute to the rise of AICs. My modest intention is not to construct a new theory about the emergence of the AICs, but rather to converge two existing discourses in the social sciences, namely globalization theories and sociological analysis of the emergence of the AICs. To this end I engage with work on Zionist AICs in South Africa by Martin West (1975), on Zionism in Soweto by Jim Kiernan and on Zulu Zionism in Durban (1990), and by Allan Anderson on the Zion Christian Church in Soshanguve (1995). I situate their findings against deve lopments in the rest of Africa, as outlined by Bennetta Jules-Rosette (1989). For insights into globalization and its application to religion, I use Peter Beyer's (1994) and Roland Robertson's works. Beyer combines four world-system theorists, so that globalization can be seen as resulting in a global economy (Immanuel Wallerstein), a global culture (Robertson), a global society (Niklas Luhmann), and a global polity (John Meyer).

The rest of this article is organized into the following sections: First, I outline some empirical data concerning linguistic and economic characteristics of AICs based on surveys conducted by the Human Sciences Research Council (HSRC) and by Anderson $(1992,1995)$. Then I review the usual arguments put forward for the emergence of AICs as a precursor to a summary of De Wet's theory about Transkei Zionism. In a third section, I briefly present Beyer's sketch of four major globalization theories, before venturing to apply them to the emergence of AICs.

[Page 105]

Journal of World-Systems Research

\section{EMPIRICAL PROFILES OF AFRICAN INDIGENOUS CHURCHES}

Various names have been used for what I will refer to as African Indigenous Churches (AICs). The most recent incarnation is African Initiated Churches, which replaced older forms such as African Indigenous Churches or African Independent Churches (compare West 1975, Daneel 1987, Anderson 1995 and Masuku 1996 for fuller discussions). National survey data still prefer "African Independent Churches" (HSRC 1993).

South African AICs are commonly grouped into Ethiopians, Apostolics, and Zionists. These distinctions point to ontological, historical and doctrinal differences. Ethiopian churches were the first to emerge in South Africa, and exhibited anti-racist and PanAfricanist tendencies, while retaining the organization and doctrines of the whitedominated Protestant churches that they broke away from. Zionist churches emerged later. They are pentecostal, emphasize faith healing, and members wear distinctive uniforms. Apostolic churches lay claim to Apostolic succession, in which the authority of 
leaders is seen to derive directly from Christ's Twelve Apostles (compare Sundkler 1961:38-59; West 1975:190; Garner 1998).

The threefold distinction is not without complications. Although these names derive largely from the titles claimed by the churches for themselves, some AICs reject the label "Zionist" - even though they mirror the organizational and religious forms of other churches who do describe themselves as Zionist (Daneel 1987:39-41). As a result some scholars invent their own terms, in which Zionist-Apostolic AICs are often grouped together. So Daneel prefers "spirit-type" churches as an umbrella term for both Apostolics and Zionists. Anderson uses "African pentecostal-type churches" for "AICs in Southern Africa related to the pentecostal churches, including the so-called 'Zionist' and 'Apostolic' churches" (Anderson 1995:284). More careful research has demonstrated significant differences between Apostolics and Zionists (Garner 1998).

As the threefold Southern African distinctions are difficult to maintain in comparisons across Africa, some scholars prefer to subsume AICs under the umbrella term "new [African] religious movements", e.g. Benetta Jules-Rosette (1989). Jules-Rosette estimates that more than 300 such new forms of African religion have emerged since the turn of the century. New African religious movements can also be subdivided into three more generic terms: (a) indigenous or independent movements, characterised by the formation of their own doctrines (the equivalent of Zionists); (b) separatist movements, which break away from existing religious structures (the equivalent of Ethiopians); (c) neo-traditional movements, which attempt to revive older traditional religious practices (Jules-Rosette 1989:148). Southern African scholars seem to use AICs in a way that combines the first two of Jules-Rosette's types. For the sake of simplicity I will use "Zionist" to refer to South African churches who label themselves as Zionist, and AICs for other types of African indigenous churches.

AICs are more numerous in South Africa than anywhere else on the continent (Daneel 1987:43). South Africa's more than 6000 AIC denominations are found mostly in the central and northern parts, i.e. the Free State and former Transvaal areas (Zaaiman 1994:572).

AICs are perceived as being among the fastest growing religions in Africa, and form the largest single religious grouping in South Africa. Estimates of AIC affiliation in South Africa rose from $9,6 \%$ of all blacks in 1940 to $20 \%$ in 1960 ; to $37 \%$ in 1991 - perhaps even to 47\% (Daneel 1987:25; Hendriks 1995, Anderson 1995:287). One out of five South African Christians belong to the AICs, as do almost one out of every three blacks (Chidester 1992:114; Zaaiman 1994:570). Recent estimates place the number of AIC affiliates at about ten million South Africans (Anderson 1992:59). This phenomenon is not limited to South Africa alone: by 1989 AIC members comprised about $15 \%$ of the Christian population of Sub-Saharan Africa (Jules-Rosette 1989:149).

[Page 106]

Joumal of World-Systems Research 
Although AICs in West and South Africa are known to draw large numbers of adherents from the historic mission churches, this is not the case for Shona adherents in Zimbabwe. About $60 \%$ of these had never been full members of any other church. Some had attended and received instruction from the mission churches (Daneel 1987:98 -9). Anderson found in a survey conducted between 1990-91 in Soshanguve that between $26 \%$ of Pentecostal-type church members and $36 \%$ of Ethiopian-type church members had not belonged to any church prior to joining AICs. By contrast, 35\% of Pentecostaltype church members and 39\% of Ethiopian-type church members had belonged to a mission church before joining the AICs (Anderson 1992:77).

Zionists comprise approximately $80 \%$ of the AICs. One of the best known Zionist churches is the Zion Christian Church (ZCC) - the largest Zionist denomination. The growth of the ZCC is attributed to several reasons, most similar to those advanced for pentecostal churches, others peculiar to Africa. Sotho-speakers form the largest single language group within the ZCC at 46.4\%; similarly Anderson notes that in Soshanguve $51.5 \%$ of ZCC members were Northern Sotho (Anderson 1992:63). Many Zionist congregations typically meet outdoors.

Researchers frequently point out that AICs draw recruits from the poorest sectors of society. Of all AIC categories in the HSRC's 1993 survey, "Other African independent churches" (i.e. excluding the Zion Christian Church, Ethiopians, and Apostolics) had the lowest income and education levels. Almost $64 \%$ of all nominal "other" AICs members belonged to households who earn less than R600 per month, while $64.2 \%$ had a "Std. 3 or less" education. An estimated $50.3 \%$ of ZCC members were part of households who earned less than R600 per month, while $59.7 \%$ had Std. 3 or lower qualification. Put differently, $11.03 \%$ of all South Africans who earn less than R600 per month claimed to belong to the ZCC, as did $12.9 \%$ of all South Africans who had Standard 3 or less (HSRC Survey 1993).

Ethnic groups are distributed evenly throughout the AICs. Of those who belong to AICs, some 36\% were Swati- and Ndebele-speakers. Xhosa-speakers comprised the largest single language group within the Ethiopian churches at 39.4\%. Within the Apostolic churches, (Northern) Sotho-speakers form the largest group (37.4\%). Of those in the "Other Independent churches" category, 42.8\% were Zulu -speakers (HSRC Survey, 1993).

\section{TYPICAL ARGUMENTS FOR THE EMERGENCE OF THE AICS}

The emergence of AICs within Africa as a whole can be periodised in terms of three peaks: the 1880 s, 1914-1925, and 1930 to the present (compare Jules-Rosette 1989:1478). Daneel argues that the Ethiopian AICs were strongest between 1890 and 1920, and started declining from the 1930s (Daneel 1987:45,53). 
In South Africa Zionist churches emerged between 1917-1927, and were at first localised in the northern provinces (De Wet 1994:152). The growth of Zionists occurred from 1920 on (Daneel 1987:38,40,45). From the 1930s on, AICs became the fastest growing sector in the religious market. The Shona Zionists grew fastest during this period (Daneel 1987:55). Southern Xhosa-speaking regions (Ciskei and Transkei) proved more resistant - although "a few Zionist churches ... occurred in the Transkei from about the 1930s" (De Wet 1994:152).

[Page 107]

Journal of World-Systems Research

During the period from 1960 to1980 AICs gained more followers in the southern areas, so that $2-5 \%$ of the Ciskei and $10-15 \%$ of the Transkei population had become members, of whom 71\% were Zionist-Apostolic (De Wet 1994:153). Between 1939 and 1955 the number of AICs doubled (from 600 to 1286 respectively) (Anderson 1992:58). By the 1950s Zionist and Ethiopian AICs "were powerful forces" in Natal and Transvaal (De Wet 1994:152). Their growth accelerated after 1955, doubling in five years to 2200 in 1960, and slowing down between 1960 and 1970 (Daneel 1987:38,40,45), increasing to "only" 3000 in 1970 (Anderson 1992:58).

Among the better known arguments for why AICs emerged are those of Bengt Sundkler (1961) and David Barrett (1968), which have been adequately summarised by Daneel (1987), Da Silva (1993), Pretorius (1995), and critiqued by Kruss (1985). The reasons vary from individual motivations to institutional innovation, and tend to focus on intraand inter-societal factors.

In this section the more frequently cited explanations will be covered in general terms, with those that are useful for the theme of globalization referred to later on. The emergence of AICs has been explained in cultural, political, and economic terms, typically associated with the impact of a capitalist economy, a colonial political structure, and an alien religious belief system on African societies. Other commonly cited factors are: (a) disappointment with Christianity; (b) translation of the Bible into different indigenous languages; (c) denominational divisions, and a failure to meet local needs; (d) a desire for physical healing; (e) a desire for community (Jules-Rosette 1989:148)

The variation among AICs in relation to historical changes and to location should be accounted for in any attempt to construct a theory about their origin and development. In addition, the factors that lead to the emergence of AICs are not necessarily those that sustain them, or that characterise later stages of their history (Daneel 1987:68). For instance, Ethiopian churches emerged as a response of protest against white domination, and initially expressed a pan-Africanist desire for liberation which slowly dissipated and is missing from current Ethiopian churches (Daneel 1987:38, 51). Yet among the Shona 
AICs of Zimbabwe protest did not play a significant causal role. AICs in West Africa represented security in "the midst of crumbling traditional structures" (Daneel 1987:71).

Among the more typical arguments for the emergence and growth in the number of AICs are the following:

1. Prolonged contact between non-indigenous and African belief systems (embedded in Western cultural systems). The growth of AICs fit the function of religion as a form of cultural defense, which arises in a context in which ethnic identity is perceived as under threat (cf. Wallis \& Bruce 1992:17-8). So even the present non-racial ideology of the African National Congress (ANC) may contribute to the growth of AICs under the Zulu a hypothesis which awaits empirical confirmation by a longitudinal breakdown of AIC growth according to ethnic grouping. AICs accept and promote certain traditional belie fs and ways of life, which contrast with the dismissive attitudes towards these matters within the mainline churches (cf. West 1975). Yet contact and social change by themselves cannot be the only major causal factors; the extent, persistence, intensification, "interference by the out-group", and level of tolerance towards change should be added (Daneel 1987:79).

2. Cultural responses to secularisation. Jules-Rosette argues that the multiplication of new African religious movements (of which AICs are one form) are cultural responses to secularisation, which take one of four forms (1989:156-7):

a. neotraditionalism, in which references to an idealised past are used to re-establish an authoritative tradition (such as African Traditional Religion);

b. revitalisation, in which new religious concepts are used to renew older traditional ones (e.g. AICs, fitting ancestors into new cosmology alongside God). This represents a cultural attempt to re-sacralize "dominant traditional symbols" through preserving "customary notions of community and conventional expressive symbols":

c. syncretism, in which old and new concepts are combined;

d. millenarism, in which an ideal future is posited, with new definitions of the sacred and a new social order. Millenarism represents a cultural attempt to redefine social and political values.

[Page 108]

Journal of World-Systems Research

Because African New Religious Movements (NRMs) involve the adjustment of Western religious systems, or the addition of new doctrinal systems to the Western ones, they 
represent Africanised forms of religious identity - not Westernised forms of African religions. Discussions of AICs tend to view the alteration of African values and forms of social organisation in terms of change towards Western forms. Instead, Jules-Rosette argues that AICs represent the adaptation of Western forms to the African context. The ultimate outcome envisaged here is that new forms of identities are emerging, which combine African and Western elements. They contribute towards "new forms of cultural expression, such as discourse and dress" (Jules -Rosette 1989:159). Similarly Lamin Sanneh (1994) argues that the translation of the Scriptures in Western Africa led to indigenous languages being held in a high regard in African churches, which contributed to the development of resistance to colonialism. Jules-Rosette regards secularisation as a result of modernisation, which is also a spin-off from globalization.

Jules-Rosette argues that where AICs engage in fundamentalist Scriptural interpretations, this "serves to develop a new fabric of ideas through which individuals attempt to create alternative types of social relationships" (Jules-Rosette 1989:159). According to Sanneh, Christianity - through translation of the Scripture into indigenous languages - opened up new possibilities for Africans to define themselves. Pride in indigenous languages bolstered nationalist movements in their struggle against colonialism. An African content is given to doctrine and leadership structures - e.g. in Nigeria in the Native Baptist Church movement from 1888 onwards, and in the Aladura revival in Yorubaland between 1928-1930 (Sanneh 1994). African religious identities in West Africa have been changed in different ways through contact with Islam and Christianity.

According to Jules-Rosette (1989) developments in African religions in fact affirm African robustness in resisting, creating, and adapting to changing environments. From this perspective AICs represent the emergence of a new African identity, which spans traditional and modern cultural practices. The innovation of AICs lies in "unique forms of social and political organization" and in the development of their own doctrines (Jules Rosette 1989:149). AICs in Zaire (Kimbanguism) and the Ivory Coast (Harrist Church) have supported political movements. In South Africa the members of most Zionist churches individually supported the ANC, according to a pre-election poll.

2. After a wide-ranging systematic study of 336 "tribal" units, David Barrett suggested a general theory based on the conclusion that the primary cause of AIC growth was as a reaction to missionary activities. His thesis is that "independency is a societal reaction to mission arising out of a tribal zeitgeist or climate of opinion in which Christian missions were believed to be illegitimately mounting an attack against African traditional society and in particular its basic unit, the family" (Barrett 1968:74). According to Barrett national, "tribal", and mission factors all play a role. National factors that produced AICs occured in societies that had a large number of Protestant missionaries, a relatively high ratio of whites to blacks, higher standards of living for whites than blacks, and a high percentage of literates. "Tribal" factors included polygamous tribes with ancestor worship. Mission factors included regions where missionaries had been working for a long period, and the Bible had been translated into an indigenous language (Daneel 1987:73-5). 
The individual religious motivations of those who start or join AICs should not be neglected. Daneel contests that AICs flourish because they present a vigourous, indigenous, and "symbolically intelligible" alternative religion which does not reject all traditions out of hand. This recalls Cox's comment about the growth of pentecostalcharismatic churches: that they grow because they offer a comforting emphasis on a miracle-working God which can deal with people in the here and now (Cox 1995).

[Page 109]

Journal of World-Systems Research

3. Some researchers contend that the social structure of particular ethnic groupings favour the formation of $A I C s$, e.g. the Tswana and the Swati. In the case of the latter the "custom of a kinship group to secede and become independent on the death of the head of the family is projected directly onto the structure of the church" (Daneel 1987:69, 86-8). Similar patterns were noted for the Luo of Kenya and in southern Malawi. Schism is also far more common among Protestant denominations than in the Roman Catholic Church, although not exclusively so, as breakaways in Zambia and Zaire in the $1950 \mathrm{~s}-60 \mathrm{~s}$ show (Daneel 1987:88).

4. Passive resistance to white political domination and cultural control of colonial church structures. In South Africa the resistance of Africans to the colonial economies and belief systems were highly successful until the destruction of their political systems through warfare (compare Kiernan 1995, Chidester 1992, De Wet 1994). The breakaway from white dominated mainline denominations around the turn of this century indicate a mixed source of rejection of racism and assertion of Africanist identity.

5. The growth of the Zion Christian Church $(\mathrm{ZCC})$ is related to the continuing urbanisation of rural South Africans. Zionist churches form important bridges in the rural-urban and the Western-African continuums. The link that exists between urbanisation and increasing ZCC affiliation directly contrasts with the commonly accepted notion that urbanisation contributes to secularisation (cf. Brown 1992:47). The growing numbers within the AICs confirm that a linkage exists between religious vitality and urbanisation which has not yet levelled off. More Indigenous churches emerged in the urban areas of the Reef "than in any other urban area in the whole of Africa"; obviously due to migratory labour - this despite AICs being essentially a rural phenomenon, with urban congregations usually established only subsequently (Daneel 1987:102-3).

6. The eventual relaxation of legislation, which recently made it easier to register these churches than was the case before (Oosthuizen 1994). Claassen has shown how by 1945 "not a single Zionist church had received government recognition" (Claassen 1995:32). 
7. The level of intimacy and care offered by Zionist churches - financial and otherwise which cannot be matched by larger mainline congregations (cf. Kiernan 1990a).

Two comments need to be made concerning the inherent limitations of these reasons, and their possible contribution to a discussion of the effects of globalization. First, for the most part the causative factors outlined above restrict the focus to economic and political change at the societal level, whether in South Africa or Africa at large. Although global trends (capitalism, colonialism) are touched upon, the expansion and dynamics of such institutions as part of a world system are not considered. Second, some concepts hint at and so could usefully fit in with - globalization. These include acculturative factors, cultural and social disintegration, religious competition within the same area, the structure of tribal organisation, industrialization, urbanization, rising secularism, and rapid social change (Daneel 1987:69-88).

To better illustrate the articulation of global economic dynamics with cultural change we now turn to De Wet's extended case study of Zionist-Apostolic in the Transkei.

[Page 110]

Journal of World-Systems Research

\section{The emergence of Zionist indigeneous churches in the Transkei region}

De Wet (1994) focuses on social, political, and economic reasons for the emergence of Zionism among Transkei Xhosa. During the 19th century, two cultural responses emerged among the Xhosa in reaction to colonialism: a traditionally-oriented Babomvu (or "Red") worldview and the Christian-oriented "School" worldview (De Wet 1994:139).

According to De Wet, up to 1980 most people in the Transkei were Babomvu people (compare 1994:137,161), as can be illustrated from the low numbers of people in this area who claim to be affiliated to Christianity. As recent as the $1960 \mathrm{~s}, 77 \%$ of the indigenous people living in the eastern Transkei claimed no church affiliation, while the overall figure for rural Transkei areas were between $41.8 \%$ and $48 \%$ (De Wet 1994:145,149).

At first the Babomvu were in the majority, managing to maintain traditional cultural practices by shunning all things Western, including Christianity and Western education. Babomvu would not allow their children to mix with School children, for fear of cultural contamination. They also resisted being drawn into the emerging migrant labour system. Most Babomvu could make a subsistence living on ancestral lands, and practised traditional beliefs and cult, for which purposes (anong others) cattle were kept. In this 
way their economic, religious, kinship, and political system intertwined and remained intact, additionally insulated by the remoteness of their rural homesteads.

Towards the end of the 19th century, social change in the Transkei happened as a result of the cumulative effect of a number of events. A severe drought, crop failure, and cattle disease destroyed the economic base of the Babomvu culture. Slowly the Babomvu were drawn into migrant labour and a monetary economy for short periods, so that they could build up their homestead. When they lived in towns as migrants, they continued to practice a cultural separatism and consumer asceticism towards all things Western, so that the essential features of the Babomvu ideology remained intact (De Wet 1994:137,146). Abantu Babomvu dressed differently, "kept apart from school and town people", and only bought western goods as was necessary (De Wet 1994:148). The Babomvu ideology was retained through the development of rites of passage, departure, and purification - which cast the new migratory experience in a traditional light, as McAllister (1980) has described (De Wet 1994:147).

Under a development program known as the Betterment Schemes, proclaimed in the 1930 s and implemented in the 1950 s and 1960 s, people were moved from their traditional homesteads into towns, were they had to live next to strangers instead of kin. This severely disrupted their land-based ancestral cult. They were given limited grazing land for cattle, and, in ignorance of the role of cattle in maintaining ritual and political structures through the kinship system, many were forced to reduce their herds (De Wet 1994:151).

Subsequently the material and relational base underpinning the Babomvu worldview was substantially weakened. Their geographical insulation was broken with the exte nsion of roads, telephones, radio services, and education systems throughout the Transkei (De Wet 1994:150). No longer able to survive through subsistence, they became increasingly drawn into migrant labour. The longer absences of males from home made main taining the ancestral cult even more difficult.

[Page 111]

Journal of World-Systems Research

According to De Wet's interpretation, in this situation of extreme social change, the worldview of the Abantu Babomvu could no longer adequately service their altered needs and they were forced to adopt another. Unwilling to assimilate to Western culture, to opt for the mission Christianity of the School people, or the Ethiopian alternative and the radical rejection of ancestral beliefs which that would entail, they increasingly found a home in Zionism (De Wet 1994:152). Zionism offered a midway route between preserving selected traditional practices and an Africanised Christianity as vehicle for adjusting to a modernising environment. 
De Wet's arguments can be summarised as follows: in the initial period the Babomvu was able to resist alteration to their traditional structures and belief systems by sustaining their material conditions and cultural isolation, supported by the construction of a vigorous worldview. During the second phase the material and political base of the Babomvu were undermined, causing alterations in ritual and social patterns. Finally, due to increasing participation in migrant labour and cultural pressure, the Babomvu had to abandon most of the old worldview for a Zionist-Apostolic ideology, yet managed to retain some older ritual aspects (De Wet 1994:154).

In other words, Zionist churches emerged in the Transkei of the early 1930 s, but became visible only in the 1950s; and grew significantly between 1960 and 1980. Dependency on wage labor increased between 1910 and 1930, so that by the late 1930s about a quarter of all economically active males were involved. This period saw the emergence of a small number of Zionist churches in the Transkei. Labor migrancy was spurred on by the implementation of Betterment Schemes between the $1950 \mathrm{~s}$ and $1960 \mathrm{~s}$, coinciding with an increase in Zionist affiliation. By the 1980 s some $80 \%$ of all males over the age of 16 were engaged in migrant labour, by which time $10-15 \%$ of the population of the Transkei had affiliated with AICs - of which 71\% were Zionist-Apostolic.

\section{GLOBALIZATION AND WORLD-SYSTEMS THEORIES}

In what follows, I will depend heavily on Beyer's succinct summaries of the contributions of four proponents of globalization theory: Immanuel Wallerstein, Roland Robertson, John Meyer, and Niklas Luhmann. Readers should note that Beyer's summary, although generally accurate, is his interpretation of the theorists. I follow his argument here to the extent that it furthers my consideration of the global effects on AICs.

The primary feature of globalization theory is that its unit of analysis is the entire globe, perceived as a single social system with distinct properties which constrain and enable all other social forms such as polities and cultures (Beyer 1994:14,16).

Robertson argues that there are four possible ways for "conceiving global order" on the basis of Toennies' classic Gemeinschaft/Gesellschaft distinction (Beyer 1994:28). These account for how societies perceive their own ideal order, and for how the global system should look (Beyer 1994:28):

a. one Gemeinschaft (communitarian) image is of a system of "closed societal communities" and "more or less incommunicable identities" (Beyer 1994:29). A second Gemeinschaft image desires "a single global community (Beyer 1994:29);

b. one Gesellschaft image views the global system as "an association of open societies" (Beyer 1994:29). A second Gesellschaft image is of a global order deliberately organised as a system, e.g. under a world government (Beyer 1994:29). 
[Page 112]

Joumal of World-Systems Research

For Luhmann there are three ways in which the global society can be perceived (Beyer 1994:40):

a. "in terms of what it is not" (e.g. Wallerstein's socialist future);

b. in terms of pre-modern categories (e.g. Robertson's communitarian orientation);

c. in terms of substituting a part for the whole (e.g. Meyer's polity).

Globalization theories can loosely (and somewhat inaccurately) be grouped into those which focus on centripetal processes which draw the world into a single place, resulting in the concentration of power and capital in certain states; and centrifugal processes which decentralize power and capital.

Globalization as a centripetal processes that leads to the continuous expansion of the global economic system

Globalization theories which focus on centripetal processes describe the continuous expansion of the global economic system (Wallerstein), accompanied by the consequent globalization of cultural structures (Robertson), technological structures (Meyer), and religious structures (Beyer 1994). As a consequence the core is strengthened while the relative weaknesses of the peripheries are reproduced. As a result, Western cultural forms dominate local material and non-material cultural forms.

\section{The global system as a world-economy - Immanuel Wallerstein}

For Wallerstein, the global system is a world-economy with a single division of labour, which emerged in Western Europe in the 15th century. For Wallerstein nation-states are a "dependent function" of "a single logic of the world-economy" (Beyer 1994:18). The world-economy led to the rise of the modern nation-state, and created three geographical divisions: the periphery, the semiperiphery, and the core. States do not control the worldeconomy but are themselves controlled by it (Beyer 1994:17). The position of a nationstate in the global division of labor determines its place (in the core, periphery, semiperiphery), strength, and its position in the class structure of the world-economy. So, for example, semiperipheral areas function as a middle class. The world-economy is driven by class conflict, disguised as racial or ethnic conflict by a global "ideas-system". Globalization has been described as a historical-political project driven by the state 
managers of the core in conjunction with their counterparts in the periphery (McMichael 1996).

[Page 113]

Journal of World-Systems Research

Core states are complex, exhibiting mixed economies and co mbining high technologies with high wages. Periphery nation-states supply the core with staples and raw materials, and are characterised by low wages and obsolete technology. Semiperiphery states (e.g. Brazil) form a permeable barrier between the core and periphery, exploiting the periphery and being exploited by the core. The semiperiphery prevents wholesale revolt thus stabilising the system. Core states redistribute wealth internally, in order to protect the vested interests of the ruling class. Periphery states are generally-speaking weak, as their ruling classes are often complicitous with the ruling classes of core states, who also subvert the peripheries through various measures (Beyer 1994:18).

Another dependent function is the emergence of an ideas -system to overcome contradictions in the world-economy. The world-economy requires both the removal of all social barriers that hinder the operation of the market, and the unequal distribution of wealth necessary for the accumulation of capital. The universalistic-egalitarian ideas promoted by the first requirement are countered by particularistic-inegalitarian notions generated by the ideas-system, such as race, ethnicity, and nationalism. These cultural notions are so pervasive that anti-systemic movements that oppose the world-economy cannot but take them into account (Beyer 1994:18).

The world-economy is characterised by cyclical trends, driven by class conflict between those who benefit from it, and those who do not (Beyer 1994:18). But cycles also result from the contradictions within the capitalist mode of production. Capitalism needs "constant expansion to maintain profit margins", and new economic opportunities have to be found continually - "often in different areas" (Beyer 1994:19). This process causes economic upturns and downswings (Beyer 1994:19).

\section{The world-system as a system of nation-states - John Meyer}

In John Meyer's version of globalization theory, the globe is understood as a system of nation states - what Robertson calls a world-political culture (Robertson 1994:105). Here a nation-state's internal strength is not determined by its position in the division of labor of the world-economy. Instead, the degree to which it conforms to world norms determines whether its legitimacy is accepted by other states (Beyer 1994:23). Legitimacy is a reward for conforming to two particular world cultural norms: equality and progress. States that profess conformity to these norms are allowed internal 
monopolies of power. So, for Meyer it is possible that strong, centralized states can develop in the periphery - not only at the core (Beyer 1994:23).

In other words, the world-polity system functions independently of the world-economic system, as illustrated by the internal dynamics of states. That is, it contains two logics: polity and economics. Further, Meyer believes that the world polity is decentralised, and is held together by a world culture (Beyer 1994:25). Meyer's arguments are made possible by his theoretical distinction between polity and economy, based on different systems of value creation (Beyer 1994:22). The economy creates value through commodification, while the polity creates value through collective authority, by constructing and bestowing value on selected activities. These values are not dete rmined by market forces, but by the authority of the polity. For example, the state as a dominant agent of collective authority can place a high value on social services. Polities include religious and cultural organisations (Beyer 1994:22).

[Page 114]

Journal of World-Systems Research

\section{The world system as a global culture - Roland Robertson}

For Roland Robertson globalization is a process that results in a global culture. He defines globalization as "the overall process by which the entire world becomes increasingly interdependent, so as to yield a 'single place' ... a world society"'. So, "subunits of the global system can constitute themselves only with reference to this encompassing whole. This is what Robertson means by relativization". Globalization relativizes identities: national identities can now be constructed only by reference to "the global system of societies", while individual identities have to refer to "humankind". In other words, globalization universalizes the particular (distinct national/individual identities) and particularises the universal (global order/humankind) (Beyer 1994:27,28).

The globalization process involves a paradox: (a) the world becomes a single place, in which (b) the expectation exists that societies "should have distinct identities"" (Beyer 1994:28). The process is not supported by a single dominant image of global order, supplied by a world culture. Instead, societies construct their own images (national identities), which not only reflect what the world should be like, but conflict with those of others (Beyer 1994:27). In their attempts to deal with these conflicting images, a global culture is produced around the idea that the world is a global whole (Beyer 1994:27).

According to Robertson five phases can be distin guished in the development of globalization:

a. a germinal phase (15-18th C) through 
b. an incipient phase (mid-18th C) to 1870 s),

c. a take-off phase (1870s to mid-1920s),

d. a struggle for hegemony phase (mid-1920s to late-1960s), to

e. an uncertainty phase (late 1960s to early 1990s) (Robertson 1994:58 -59).

Robertson believes that religion can encourage the formation of particular nationalindividual identities, or provide world theologies that promote an inclusive view of humankind (Beyer 1994:29,30). Globalization causes church-state tensions, as religion is becoming increasingly politicised, while politics are becoming increasingly theologised (Beyer 1994:30). Jules-Rosette raises a similar point when speaking about resacralising, which includes political goals.

[Page 115]

Joumal of World-Systems Research

\section{The world system as a global society - Niklas Luhmann}

Niklas Luhmann argues that a global society exists because communication "extends continuously around the globe" (Beyer 1994:31). In other words, Luhmann provides insight into the structure of global society (Beyer 1994:33). He argues that society is a social system, in which actions occur, based on meaningful communication (Beyer 1994:30). And so "increasingly, meaningful communication can and often does take place between any two points" (Beyer 1994:30). Communication, in turn, depends on relatively stable social structures, based on expectations (Beyer 1994:36). The kind of communication that has become globalized is cognitive or adaptive; e g. scientific, technical, news, travel (Beyer 1994:36). Modernization leads to globalization, and so to a world society (Beyer 1994:38).

One of the most important shifts from pre-modern to modern societies is from a normative to a cognitive (learning) way of responding to disappointed expectations (Beyer 1994:37). Learning is increasingly important in modern social structures (Beyer 1994:36). Another shift is from the dominance of stratified differentiation to that of functional differentiation (Beyer 1994:34):

i. In stratified differentiation, , people are ranked on the basis of status, so that their actions are interpreted according to strata membership. Stratified societies are characterised by the dominance of a ruling strata, who control most of the power. The boundaries of society is determined by "the reach of their communication" (Beyer 1994:35); 
ii. In functional differentiation people and their actions are categorised on the basis of the function that they fulfill in specific (political, economic, educational, religious) systems (Beyer 1994:35). Such systems "specialize in specific modes of communication" (Beyer 1994:37). By implication, this sets boundaries which are relatively independent from one another, so that one system cannot control others. The "only boundary that remains possible for the encompassing societal system is then the globe itself" (Beyer 1994:38). World society is characterised by "the dominance of functionally differentiated subsystems" (Beyer 1994:40).

\section{Globalization as centrifugal processes that lead to radical fragmentation}

In contrast to the above, other globalization theories exist that focus on centrifugal processes which are seen to radically realign the world-system. Fundamental changes are brought about by a decentralisation of capital, which weakens the center while strengthening the periphery (Friedman 1994). Whether viewed in terms of centrifugal or centripetal conceptualizations of the world-system, the notion that the shift began in 1970 seems widely supported (compare Featherstone 1990). A particularly relevant aspect of Friedman's perspective is the premise that the decline of hegemony leads to an increase in expressions of different cultural and social identities.

[Page 116]

Journal of World-Systems Research

\section{GLOBALIZATION AND THE EMERGENCE OF AICS IN SOUTH AFRICA}

My modest intention is to show that globalization contributed to the emergence of AICs by affecting African religious identities through radically altering economic and cultural systems. In other words, in both subsections altered religious identities are in focus; with the difference that in the first subsection this is viewed in terms of global economic trends. Changes in African cultural and religious identities are linked to the initial expansion of the world-economy and its need for cheap migratory labour, sustained by "development" and its drive towards modernization. In the second subsection, global cultural hegemony is the primary focus. The emergence of the AICs as new forms of African cultural and religious identities is connected to the cycles of core state hegemony within the world-polity, accompanied by a global extension of cultural products (e.g. language) and institutions (e.g. education, religion).

The implied separation of economy from culture is theoretically possible, but analytically difficult to sustain due to the articulation of the one with the other. Strictly speaking, economy has to do with the production, distribution, and consumption of commodities; while culture has to do with the communal production and transmission of patterns of thinking and acting. But the globalization of Western systems of education, language, 
economy, and religion effected not only the division of labour between core and periphery and within the periphery, but also radically altered social structures and belief systems.

\section{AICs and the expansion of the world-economy}

In this section, I describe the effect of globalization on African religious and cultural identities by using Africa's incorporation into the world-economy as point of departure. The descriptions are pensketches and largely confined to South Africa; but the unit of analysis remains global. In other words, events unfolding in South Africa are viewed against the global system as a primary constraint. By implication, the global system created similar effects elsewhere, such as new religious movements across Africa, Asia, and Latin America, but these would take different forms depending on the local configurations of e.g. the political economy.

Colonialism was part of the early expansion of the capitalist world-system, which led to the formation of nation states in Europe and in the colonies. Pre- and post-colonial subSaharan African societies were peripherally integrated into the world-economy. This dependency was mirrored internally with the emergence of urban centers and rural peripheries. "Globalization is not simply a matter of societies, regions and civilizations being squeezed together in various problematic ways but also of this occurring with increasing intensity inside nationally constituted societies" (Robertson 1994:104).

By the end of the colonial period the global "hegemony of the Western free-market economy" had been well established in South Africa as elsewhere (Heugh 1995:330). South Africa was incorporated into the world-economic system as part of the periphery, and exploited by the colonial core for mineral and other commodities - gold exports formed 60\% of exports between 1909-1937 (Milkman 1979:269). African economic and political systems were radically altered, particularly as the need for cheap labor resulted in the disintegration of ritual systems caused by the absence of males for extended periods from the homestead due to migrant labor. New forms of ritual developed to match the new form of labour, so that e.g. rites of passage emerged around migrant laborers' leaving home for urban areas (McAllister 1980). The large-scale effects on African belief systems were (a) desacralisation of African belief systems; (b) structural differentiation; and the transfer of religious meanings to a secular setting (Jules-Rosette 1989:153). In such a context, the development of indigenous churches, prompted by the experience of migrant labourers at their places of work, "inevitably acquired overtones of ethnic and tribal defiance" (Van Binsbergen 1994:154).

[Page 117]

Journal of World-Systems Research 
South Africa became a semiperipheral state during the period following World War Two (compare Martin 1990:219; Wallerstein \& Vieira 1992:5; Milkman 1979:262). After 1948 a manufacturing industry developed, supported by direct foreign investment, restrictions on consumer imports alongside an import substitution industry, and importation of capital goods (Milkman 1979:261,266-7). Yet, by $1972,60 \%$ of all exports continued to be raw materials, of which 37\% was gold (Milkman 1979:272). South Africa's potential to be eventually incorporated into the core was constrained by the policies of the apartheid regime and its failure to take advantage of changes in the world-system - most notably, the movement of manufacturing to the periphery. Stagnation occurred, so that South Africa not only remained in the semiperiphery but appears to be spiralling downward due largely to forces beyond its control.

During the apartheid period, an internal form of colonialism racialised class divisions. Mamdani (1996) proposes that the apartheid state continued the quintessential form of state established in the late colonial period. Just like indirect rule, apartheid created racialised urban citizens, with tribalized rural subjects under a Native Authority, "supervised by white officials" (Mamdani 1996:287). "Whites of all political and ideological persuasions" became so "comfortable with the privileges which apartheid offered them in the form of cheap black labor that they found no need to learn African languages - they were in a situation which never demanded that they associate with the African working class as equals at any time" (Maake 1994:117). In the post-apartheid era the interests of the ruling class are increasingly tied to the economic structure, which means that, state policies to the contrary, a change in the conditions of the working classes is unlikely.

State responses to the AICs mostly took the form of non-recognition (Claassen 1995), and even occasionally direct state opposition. The case of the Israelite massacre at Bulhoek demonstrates that AICs were sometimes viewed as potentially disruptive to "civic political commitments by virtue of their ability to mobilize masses of people in activities which are not directly ... controlled by the state". This mirrored state violence against e.g. the Kimbanguists in the Kongo (Jules-Rosette 1989:155).

South Africa's status in the world-economy is relevant insofar as the movement from periphery to semiperiphery was accompanied by increasing rates of incorporation of the African population into migrant labor. De Wet's work shows that in the Transkei region an escalation of migrant labor coincided with increasing affiliation to Zionist churches, so that the first factor seems directly related to the second. Yet in both of South Africa's world zone incarnations a large segment of migrant labor continued to feed into the mines, first along the Reef and later further afield. South Africa's shift to a semiperiphery through post-World War Two industrialisation was accompanied by increasing recruitment of migrant labour. As the major industries, like the major mines, were also initially situated primarily on the Reef, or in the nearby Pretoria and Vereeniging urban areas, migrant labourers were drawn to the same region, where they encountered Zionist evangelists. Labor migrants encountered Zionism and took it back home through a point to point diffusion. This explains the emergence of Zionism among low-paid manual workers. 
The close link between the spread of AICs and migratory labor can also easily be demonstrated for the rest of Southern Africa, e.g in the founding of AICs in the 1920s among the Kalanga of Botswana (Daneel 1987:102, Van B insbergen 1994). The establishment of Shona and Swati AICs happened through the interlinking of Southern Africa into mining - a function of the core in relation to the periphery in the global economy. The First Ethiopian Church among the south-eastern Shona in Zimbabwe was founded by Mupambi Chidembo, who as a migrant laborer in the Transvaal from 1890 to 1910 encountered Ethiopians. He returned to Zimbabwe in 1910, ordained as bishop, to establish congregations there (Daneel 1987:51). Similarly, the founder of the African Congregational Church in the Chipinga District had made contact with the Zulu Congregational Church in the 1930s (Daneel 1987:52). Among the Zionist-type churches, Zimbabwean Zionist churches were established after the experience that their founders (Makamba, Mtisi, Masuka) had as migrant laborers with the Zion Apostolic Church of South Africa (est. 1917) and with the Zion Apostolic Faith Mission in 1923 (Daneel 1987:54-5, referring to Samuel Mutendi who co-founded the ZCC).

[Page 118]

Journal of World-Systems Research

While membership of AICs affirm local identities, they alter them in significant ways, through rejection of certain traditions and through promoting education and agricultural innovation (Daneel 1987:56). Conversion in the colonial era was linked to the acceptance of certain economic practices, such as commercial agriculture - and arguably broadly speaking still favors capitalism. To convert from African Traditional Religions (ATRs) and to reject African practices is to become part of a global project which militates against the expression of local identities, structures, and kinship patterns; i.e. are modernising (Kritzinger 1992:301). In this way AICs contributed to the more individualistic role required by a globalized capitalist system, which is one step removed from the primary communal emphasis of African Traditional Religions (ATRs). By contrast ATR function to support local identities and maintains the functions of traditional kinship, economic, and political systems. AICs seem to offer continuity with selected aspects of a traditional past, while orienting their members to the realities of the present, as shown by Zionist churches in the Transkei.

\section{AICs and cultural hegemonies in the world-system}

In this section I describe the effect of globalization on African religious and cultural identities by referring to the establishment of cultural hegemony. The effect was to suppress local identities through the extension of mechanisms of social control, such as education and religious institutions. Peter Smith (1986) has theorized that religion is strengthened inside a core state as that state achieves hegemony within the world-system. Subsequently the core state extends its religious system to the periphery. The dominance 
of religion within the world-system waxes and wanes with the fortunes of its core state, as it does within that state. The dominance of Christianity in sub-saharan Africa is thus the residue of the core states that dominated this region.

When British hegemony was declining in the world-system, a global conflict ensued to establish a new dominant state in the core. In South Africa, this struggle assumed economic, linguistic, and racial forms, evident in e.g. the elevation of English and Afrikaans to official languages and the devaluation of indigenous cultural forms including belief systems. Mother tongue teaching during the initial years of education in black schools was replaced by the introduction of both official languages. This structured the racial division of the labor market, while ensuring the effective functioning of the economic market. A small educated black elite class was created, capable of co-operating in the divide and rule strategies over distant rural areas and of participating in the extension of Western institutions.

The continuing spread of English as the language of choice in state and civil society (despite official multilingual policies) entrenched class divisions of labor, and the coreperiphery continuum between metropolitan and rural areas. Differential access to English, dependent on level of state funding of education, structured and integrated marginal groups into the peripheral economy (Tollefson 1991:132-3).

South Africa's peripheral incorporation into the world-economy also caused an internal replication of the core-periphery dualism, with the homelands constituting the periphery. Because this was accompanied by European cultural and linguistic hegemony, labor migrants who opted to remain outside the education system became perip herally integrated into the economy (as Van Binsbergen demonstrated for the Nkoya of Zambia; Van Binsbergen 1994:147). AICs emerged during the late colonial period (1880-1925) as an African initiative to span the rural/urban, African/Western, local (African) and global (Western) divides generated by the process of globalization. Shifts from traditional African religious identity to AICs were linked to attempts to overcome the peripheral position assigned to Africans in the world-system. Christianity (and Islam) offered Africans entry into a global identity through conversion to a world religion. Like other newer forms of African religion, and unlike mainstream religion at that point in time, AICs provided possibilities of "inter-ethnic and transcultural associative networks" through "overarching symbols and doctrine" (Jules-Rosette 1989:157).

[Page 119]

Journal of World-Systems Research

One effect of globalization on African cultural identities was to promote assimilation into the hegemonic culture, seen as inevitable and even desirable. Brandel-Syrier (1978) in her study of the emergence of an African elite in a South African township in the 1960s, 
outline the mechanisms of assimilation that accompanied the acceptance of Christianity. These included enrolment in Western education systems, which produced an elite eager to assimilate to Western society.

Brandel-Syrier (1978) insists that the effect of modernisation on Africans was to cause cultural and social mobility; cultural in that Africans adopted Western practices and surrendered traditional religious beliefs; social in that Africans had difficulty in relating to their kin. Assimilation is also implicit in the lack of attention to cultural diversity in English and Afrikaans-speaking churches. This is in part due to the colonial equation of Westernisation with civilisation, and the expectation that Africans who converted should reject African traditional religious practices - particularly those associated with ancestor cults. Brandel-Syrier acknowledges (without comment) that assimilation alienated black elites from the political struggles of the 1960s townships, brought about class division within black communities, and caused role confusion in relation to peers.

Another effect on cultural identity was to erode it through acculturation, in which some aspects of African identities were retained and others altered. This is the case with Zionists, as shown by Kiernan's work. Through the experiences of urbanisation and poverty Africans construct new religious identities that combined aspects of traditional belief systems and rural ethnic identities with Christianity to form an indigenous religion.

I find West's (1975) distinction between beliefs and cult useful to describe the effects of globalization on religious identity. West distinguishes between cult (practices involving the placation of the ancestors such as slaughtering an animal) and beliefs (accepting the existence of ancestors, shades, or ancestral shades). Seen in this light, a variety of outcomes in African belief systems emerge, which can be summarised as:

i. a range of beliefs, from (a) weaker forms, in which the ancestors are seen as unimportant or sleeping; to (b) somewhat stronger forms, in which the ancestors are powerful, but only important in crises; to (c) forms in which the ancestors are important and powerful, sometimes seen as acting as intermediaries between humans and God (West 1975:203-4);

ii. a range of cultic practices, in which (a) strong beliefs correspond to strong expression of cult (regular offerings or prayer); and (b) weak beliefs and weak cult (where offerings disappear, or occur only during crises); or (c) weak belief or strong belief and weak cult (West 1975:204-5).

$>$ From this perspective, local responses to pressures towards a global identity can take many forms, and Africans can be both Western and African; both Christian and traditional. Through contact with Christianity and in pluralist township situations, Africans can adjust their cult and beliefs in several ways, ranging from strong beliefs and practise of cult to weak beliefs and little or no cult, or altered beliefs in which Christian ideas influence traditional ones. Religious identity involves both cult and beliefs, and the pluralist urban situation leads to changes in one or both. 
[Page 120]

Journal of World-Systems Research

\section{CONCLUDING COMMENTS}

I do not want to provide what Robertson calls a mono-causal explanation of AICs. As Robertson has suggested, analysis in terms of the global system should include atten tion to the voluntaristic nature of change, particularly the involvement of individuals (Robertson 1994:104). The articulation of the individual, communal, national, and global have to be accounted for. De Wet's analysis of the emergence of AICs in the Transkei provides a good example of the individual and communal levels, while providing the basis for the national and global.

Robertson's view of globalization as a process that constrains individuals and societies to structure themselves with reference to the idea of a global humankind and of the existence of the global is not obviously applicable to AICs. Religious systems with a global orientation fit in better, such as the Unification Church or Catholicity (Robertson 1987a:42). Yet, as De Wet's analysis shows, religious change relates to socio-political structures, which in turn responds to ideas generated and accepted globally (e.g. "development"). The world-political culture promotes individualism (alongside polyethnicity) and encourages its institutionalisation through state structures, but also through the activities of non-governmental organisations - such as development organisations (Robertson 1992:105).

The emergence of New African religions has to be linked, in particular, to two connected global phenomena: (a) the spread of the nation-state, which became the primary unit in the world division of labour between the core and the periphery; and (b) colonialism, which brought about westernization and the decline of traditional authority (Jules-Rosette 1989:153). Against these forces of globalization the emergence of AICs was a cultural response, in the form of either (a) giving up cultural heritage, and regarding it as inferior; or (b) rebelling against the threat to indigenous cultural identities, and the reaffirmation of traditional culture and belief systems - - the neotraditional response.

The development of the nation-state is aided by the globalization of education as a system of social control, by which cultural hegemony is established by the state over its subjects. In the context of linguistic and cultural pluralism, education (particularly in a nonindigenous language such as English) serves to structure the division of labor between the bureaucrats and technocrats essential for the functioning of the state within the worldsystem, and the rest, who are marginalised (compare Tollefson 1991). 
The globalization of the world-economy causes changes in traditional religious beliefs and authority systems in non-Western societies, as Peter Berger noted (Berger 1967:171, referred to in Jules-Rosette 1989:153). Yet, as Jules-Rosette argues, these changes are double-edged, entailing the return to traditional religious concepts which are redefined in a context of "changing political and social demands". Industrialisation is often accompanied by the formation of a substitute pre-industrial kinship group, a reestablishment of mechanical solidarity (cf. Kiernan 1990a, Jules-Rosette 1989:154).

In other words, historical and global processes transform local contexts by pushing certain cultural identities that indigenous peoples need to assume in order to achieve legitimacy in the larger system. Two responses occur: assimilation and resistance, which tend to move towards one another over time. The forced choice between alternative identities is also associated with acceptance of alternative economic, political, and social processes. Local political and social processes of state and ethnic formation, along with the pre-industrial mode of production, are disrupted. The supporting material and cultural (including religious) base of local identity is inhibited, and class differentiation promoted. Economic and cultural resistance occurs, cast in more traditional patterns, with adjustments to incorporate unavoidable newer social relations.

[Page 121]

Journal of World-Systems Research

The extremely strong link that exists between participation in the AICs and the economic position of their members seems to indicate that membership involves a somewhat transitional structure. Membership is transitional in two senses: increased individual economic welfare militates against continued membership in AICS (Kiernan 1990a) just as increased unemployment feeds into the AICS as well, while recruitment of educationally mobile youth intensifies the movement towards modernity. In the first instance, then, membership is transitional in an economic class sense. People who become economically mobile leave the movement; those who lose their jobs or who cannot find employment (an estimated 7 out 100 school-leavers will find formal sector employment in 1998) tend to become affiliated. In the second instance, a shift within the educational standing of members moves the movement as a whole towards a different place, ideologically speaking.

AICs have an anti-systemic function, but this would be radically altered should their members be drawn into the emerging black middle class. Their anti-systemic function is evident to the extent that they resist, perhaps unintentionally, being drawn into globalized identities, and construct alternative identities to those offered by either the world-system or by an idealised traditional past. By extending mutual financial care AIC members counter the negative local effects of unequal exchange. In contrast to mainstream Christianity, which arguably contributed to the establishment of a global European 
cultural hegemony, the emergence of Zionism can be seen as an attempt to retain some measure of local identity. But because this development was constrained by the global system, even local forms of identity - Zionism - have to refer to the global - i.e. Christianity.

\section{WORKS CONSULTED}

Akbar S. A. \& H. Donnan (eds) 1994. Islam, globalization and postmodernity. London: Routledge.

Anderson, A 1992. Bazalwane: African pentecostals in South Africa. Pretoria: Unisa.

Anderson, A 1995. Challenges and prospects for research into African Initiated Churches in Southern Africa. Missionalia 23 (3): 283-294.

Barrett, D 1968. Schism and renewal in Africa: an analysis of six thousand contemporary religious movements. Nairobi: Oxford University Press.

Beyer, P 1994. Religion and globalization. London: Sage.

Brandel-Syrier, M 1978. Coming through: the search for a new cultural identity. Johannesburg: McGraw-Hill.

Brown, C G 1992. A revisionist approach to religious change. In Bruce, S (ed.) 1992. Religion and modernization: sociologists and historians debate the secularization thesis. Oxford: Clarendon Press, pp. 31-58.

[Page 122]

Journal of World-Systems Research

Bulman, R F 1996. Discerning Major Shifts in the World- System -- Some Help from Theology? Review 19, 4: 383-400.

Chase-Dunn, C. \& P. Grimes 1996. "World-system analysis". Annual Review of Sociology 21: 387-417.

Chidester, D 1992. Religions of South Africa. London: Routledge.

Claassen, J W 1995. Independents made dependents: African Independent Churches and government recognition. Journal of Theology for Southern Africa 91: 15-34. 
Cox, $\mathrm{H}$ 1995. Fire from heaven. The rise of Pentecostal spirituality and the reshaping of religion in the 21st century. Reading MA: Addison-Wesley Publishing Co.

Daneel, M L 1987. Quest for belonging: introduction to a study of African Independent Churches. Mambo Occasional Papers - Missio-Pastoral series No 17. Gweru: Mambo Press.

De Wet, J. 1994. Social change, resistance and worldview of a community in the Transkei. In Oosthuizen, G C; Kitshoff, MC \& Dube, S W D (eds.) Afro-Christianity at the grassroots: its dynamics and strategies. Leiden: Brill, pp. 137-164.

Da Silva, J A 1993. African Independent Churches: origin and development. Anthropos 88: 393-402.

Featherstone, M (ed) 1990. Global culture : nationalism, globalization and modernity. A Theory, Culture \& Society special issue. London: Sage (1993 printing). Published simultaneously as vol. 7 , issue $2 / 3$ of Theory, culture \& society.

Friedman, J 1994. Cultural identity \& global process. London: Sage.

Garner, R 1998. Religion and Economics in a South African Township. PhD dissertation, Cambridge: University of Cambridge.

University of Cambridge.

Heugh, K 1995. Disabling and enabling: implications of language policy trends in South Africa. In Mesthrie, R (ed) Language and social history: studies in South African sociolinguistics. Cape Town: David Philip, pp. 329-350.

Human Sciences Research Council Omnibus Survey 1993. Commissioned unpublished survey.

[Page 123]

Journal of World-Systems Research

Hendriks, J 1995. South African Denominational Growth and Decline 1911-1991. Journal of Theology for Southern Africa 91:35-58.

Jules-Rosette, B 1989. The sacred in African new religions. In Beckford, J A \& Luckmann, T (eds.) The changing face of religion. London: Sage, pp. 147-162.

Kiernan, J 1990a. How Zionists see themselves. In The production and management of therapeutic power in Zionist Churches within a Zulu city. Lewiston NY: Edwin Mellen Press, pp. 208-222. 
Kiernan, J 1990b. African and Christian: from opposition to mutual accommodation. In Prozesky, M (ed) Christianity amidst apartheid: selected perspectives on the church in South Africa. New York: St Martin's Press, pp. 9-27.

Kiernan, J 1995b. African Independent Churches. In Prozesky, M \& De Gruchy, J (eds) 1995. Living Faiths in South Africa. Cape Town: David Philip, pp. 116-128.

Kritzinger, J J 1992. The development of African Independent churches. In Oosthuizen, G C \& Hexham, I (eds) 1992. Empirical studies of African Independent/Indigenous Churches. Lewiston: Edwin Mellen, pp. 291-312.

Kruss, G 1985. Religion, class and culture - indigenous churches in South Africa, with special reference to Zionist-Apostolics. M A Thesis, Cape Town: University of Cape Town.

Maake, N P 1994. Dismantling the Tower of Babel: in search of a new language policy for a post-Apartheid South Africa. In Fardon, R \& Furniss, G (eds) 1994. African languages, developments and the state. London: Routledge, pp. 111-121.

Mandani, M 1996. Citizen and Subject - Contemporary Africa and the Legacy of Late Colonialism. Cape Town: David Philip.

Martin, W G 1990. From NIC to NUC: South Africa's peripheral regimes. In Martin, W $G$ (ed) Semiperipheral states in the world-economy. Westport: Greenwood Press, pp. 203-224.

Masuku, T 1996. African Initiated Churches: Christian partners or antagonists? in Missionalia 24, 3: 441-455.

McAllister, P A 1980. Work, homestead, and the shades: the ritual interpretation of labour migration among the Gcaleka. In Mayer, P (ed) 1980. Black villagers in an industrial society. Cape Town: OUP, pp. 205-53.

[Page 124]

Journal of World-Systems Research

McMichael, P 1996. Globalization: myths and realities. Rural sociology 61 (1): 25-55.

McNeill, W H 1994. The Fall of Great Powers: An Historical Commentary. Review 17, 2: 123-43. 
Milkman, R 1979. Contradictions of semi-peripheral development: the South African case. In Goldfrank, W L (ed) The world-system of capitalism: past and present. Beverly Hills: Sage, pp. 261-284.

Oosthuizen, G C 1994. The South African New Age movement and the African Indigenous Church movement - a comparison. In Oosthuizen, G C; Kitshoff, MC \& Dube, S W D (eds) 1994. Afro-Christianity at the grassroots: its dynamics and strategies. Leiden: Brill, pp. 231-245.

Pretorius, H L 1995. Historiography and historical sources regarding African Indigenous Churches in South Africa. Lewiston NY: Edwin Mellen.

Robertson, R 1985. The sacred and the world system. In Hammond, P E (ed) 1985. The sacred in a secular age: towards the revision in the scientific study of religion. Berkeley: UCLA Press, pp. 347-58.

Robertson, R 1987a. Church-state relations and the world-system. In Robertson, R \& Robbins, T (eds) 1987. Church-state relations: tensions and transitions. New Brunswick: Transaction Books, pp. 39-52.

Robertson, R 1987b. Globalization and societal modernization: a note on Japan and Japanese religion. Sociological Analysis 47: 35-42.

Robertson, R 1989. Globalization, politics, and religion. In Beckford, J A \& Luckmann, $\mathrm{T}$ (eds.) The changing face of religion. London: Sage, pp. 10-23.

Robertson, R \& W.R. Garrett (eds) 1991. Religion and global order. New York: Paragon House.

Robertson, R 1992. Globalization: social theory and global culture. London: Sage.

Sanneh, L 1994. Translatability in Islam \& in Christianity. In Van Beek, W E A, Thomson, D L , \& Blakely, T D, (eds) 1994. Religion in Africa: experience and expression. London: James Currey, pp. 23-45.

Siqwana-Ndulo, N 1997. The aftermath of Betterment Schemes: land struggles in three districts of Transkei. Unpublished paper presented to the annual conference of the South African Sociological Association, Umtata, 6-10 July.

[Page 125]

Joumal of World-Systems Research 
Smith, P 1986. Anglo-American religion and hegemonic change in the world system, $c$. 1780-1980. British Journal of Sociology 37, 1:88-105.

Sundkler, B 1961. Bantu prophets in South Africa. 2nd ed. London: Oxford University Press.

Swatos, W. H. Jr. (ed) 1989. Religious politics in global and comparative perspective. Westport, Conn: Greenwood Pr.

Taylor, P J 1997. Modernities and Movements: Antisystemic Relations to World Hegemony. Review 20, 1: 1-17.

Tollefson, J W 1991. Planning language, planning inequality. New York: Longman.

Van Binsbergen, W 1994. Minority language, ethnicity and the state in two African situations: the Nkoya of Zambia and the Kalanga of Botswana. In Fardon, R \& Furniss, G (eds) 1994. African languages, developments and the state. London: Routledge, pp. 142190.

Zaaiman, J 1994. Kerk en geloofsaffiliasie in Suid-Afrika [Church and religious affiliation in South Africa]. Nederduits Gereformeerde Teologiese Tydskrif 35 (4): 565574.

Wallis, R \& S. Bruce 1992. "Secularisation: the orthodox model". In Bruce, S (ed.) Religion and modernization: sociologists and historians debate the secularization thesis. Oxford: Clarendon Press, pp. 8-31.

Wallerstein, I \& S. Vieira1992. Historical development of the region in the context of the evolving world-system. In S. Vieira, W.G. Martin, \& I. Wallerstein (eds.) How fast the wind? Southern Africa, 1975-2000. Trenton NJ: African World Press, pp. 3-15.

West, M 1975. The shades come to town: ancestors and urban independent churches. In Whisson, MG \& West, M (eds) 1975. Religion and social change in Southern Africa. Cape Town: David Philip, pp. 185-206.

[Page 126]

Joumal of World-Systems Research 